\title{
The Effect of Polysorbate 20 on Solubility and Stability of Candesartan Cilexetil in Dissolution Media
}

\author{
Katarzyna Hoppe ${ }^{1}$ and Małgorzata Sznitowska ${ }^{1,2}$
}

\begin{abstract}
Received 25 November 2013; accepted 6 March 2014; published online 29 May 2014
Abstract. The addition of polysorbate 20 (T20) is required to achieve "sink" conditions during a dissolution test for tablets with candesartan cilexetil (CC). Polysorbate $20(0.35 \%-0.7 \% \mathrm{w} / \mathrm{w})$ added to $0.05 \mathrm{~mol} / \mathrm{L}$ of phosphate buffer $\mathrm{pH} 6.5$ dramatically increased the apparent solubility of the drug from $0.8 \mu \mathrm{g} / \mathrm{ml}$ even to $353 \mu \mathrm{g} / \mathrm{ml}$, while its effect in lower $\mathrm{pH}$ or in water was much smaller $(20 \mu \mathrm{g} / \mathrm{ml}$ in pH 4.5$)$. The increased concentration of phosphate salts $(0.2 \mathrm{~mol} / \mathrm{l})$ at $\mathrm{pH} 6.5$ in the presence of $0.7 \%$ of polysorbate 20 , resulted in further increase of candesartan cilexetil solubility to $620 \mu \mathrm{g} / \mathrm{ml}$. The change of $\mathrm{pH}$ from 1.2 to 7.4 resulted in a 1.5 -fold increase of the activation energy and, depending on temperature, 8-14-fold decrease of the degradation rate. When polysorbate 20 increased the activation energy 2 -fold, independent of $\mathrm{pH}$, it protected candesartan cilexetil from degradation; however, this effect was temperature dependent and was very small at $310 \mathrm{~K}$ - the degradation rate in $\mathrm{pH} 6.5$ decreased by $13 \%$ only. It was calculated that in the phosphate buffer $\mathrm{pH} 6.5$ with polysorbate, one can expect during $24 \mathrm{~h}$ the degradation at the level of $9.3 \%$, thus a flow-through dissolution apparatus was recommended for testing prolonged release dosage forms.
\end{abstract}

KEY WORDS: candesartan; dissolution; polysorbate; solubility; stability.

\section{INTRODUCTION}

Dissolution testing has been employed as a quality control procedure in pharmaceutical production, and the objectives of dissolution testing vary during the life cycle of a dosage form. In product development, it is used to assist in the selection of a candidate formulation, in research to detect the influence of critical manufacturing variables, such as the binder effect, mixing effect, granulation procedure, coating parameters, and excipient type [1]. It, therefore, becomes apparent that the dissolution data derived from the physicochemically and hydro-dynamically defined conditions is required in order to compare various in vitro dissolution data and to be able to use such results as a surrogate for possible in vivo bioequivalence testing and in vitro-in vivo correlations (IVIVC) [1,2].

Dissolution characteristics of oral formulations should be evaluated using the test media within the physiological $\mathrm{pH}$ range of 1.2-6.8 (1.2-7.5 for modified-release formulations). Selection of the dissolution medium is based, in part, on the solubility data and its stability measured at the pre-formulation stage [2]. In order to ensure that the dissolution test is measuring the properties of drug release without the limitations imposed by the experimental conditions, the medium is selected to ensure that the concentration gradient remains large and "sink" conditions occur for the duration of the test.

\footnotetext{
${ }^{1}$ Department of Pharmaceutical Technology, Medical University of Gdansk, Hallera 107, Gdansk, 80-416, Poland.

${ }^{2}$ To whom correspondence should be addressed. (e-mail: msznito@ gumed.edu.pl )
}

"Sink" conditions are achieved when the drug solubility is 10 times the total concentration of the drug in a vessel or at least greater than three times $[2,3]$.

Candesartan cilexetil (CC), whose chemical structure is presented in Fig. 1, is a potent and long-acting angiotensin II receptor blocker, commonly used to treat hypertension in monotherapy or in combination with other antihypertensive agents, such as diuretics. CC is available as nonmodified release tablets in doses of 8,16 , or $32 \mathrm{mg}$ (an original product from Astra Zeneca and generics from e.g., Sandoz, Krka, Zentiva). CC is a pro-drug, which is rapidly and completely converted into an active moiety, candesartan, during a gastrointestinal absorption [4]. Miyabashi [5] has identified candesartan and desethyl candesartan, as a metabolite of $\mathrm{CC}$, in plasma samples.

CC is practically insoluble in water $(<0.05 \mu \mathrm{g} / \mathrm{mL})$ and is a highly lipophilic compound. The partition coefficient $\left(C_{\text {octanol }} /\right.$ $\left.C_{\text {water }}\right)$ at $\mathrm{pHs} 1.1,6.9$, and 8.9 is $>1,000$, indicating high hydrophobicity $[4,6]$. Solubility of $\mathrm{CC}$ in a simulated gastric fluid and intestinal fluid has been reported as 0.6 and $8.6 \mu \mathrm{g} / \mathrm{mL}$, respectively [7]. Low solubility of CC across the physiological $\mathrm{pH}$ range resulted in an incomplete absorption from the gastrointestinal tract and, hence, it is reported to have an oral bioavailability of about $15 \%[4,8]$. Based on CC's solubility across the physiological $\mathrm{pH}$ and absorption characteristics, it is classified in the Biopharmaceutics Classification System as a class II drug [8].

Solubility of CC in various surfactant solutions and oils has been reported. It is slightly soluble in Miglyol 812 or Labrafac and sparingly soluble in Labrafil. Polysorbate 80, macrogol 400, Cremophor, Labrasol, and Transcutol P were 


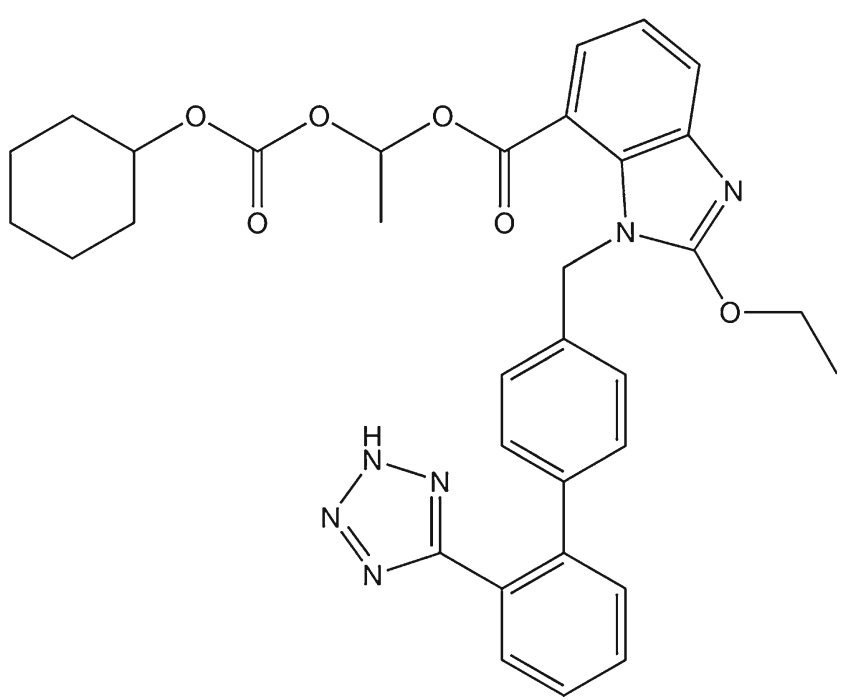

Fig. 1. Chemical structure of candesartan cilexetil (1RS)-1[[(Cyclohexyloxy)carbonyl]oxy]ethyl 2-ethoxy-1-[[2'-(1H-tetrazol-5yl)biphenyl-4-yl]methyl]-1 $H$-benzimidazole-7-carboxylate

used to solubilize $\mathrm{CC}$ in water in order to develop a selfmicroemulsifying formulation as a new dosage form [8]. In a phosphate buffer (PBS) $\mathrm{pH} 6.5$ containing $0.7 \%$ of polysorbate 20 (T20) and in PBS pH 6.8 with $1 \%$ of sodium lauryl sulfate, the solubilities have been reported as $125.0 \mu \mathrm{g} / \mathrm{mL}$ [9] and $1.0 \mu \mathrm{g} / \mathrm{ml}$ [10], respectively. This indicates how important a choice of additives in dissolution media is when "sink" conditions have to be achieved.

In its solid state, $\mathrm{CC}$ is stable against temperature, moisture, and light but undergoes degradation when subjected to acidic, basic, aqueous hydrolysis, and oxidative conditions [4, 11]. Rao et al. [12] have determined and identified several impurities of CC in alkaline or acidic conditions and under oxidative and hydrolytic stress. CC is highly sensitive to bases and is degraded to candesartan and transesterification products (methylcandesartan, ethylcandesartan, hydroxyethylcandesartan) [11, 12]. Mohan et al. [13] determined and identified five degradation products of $\mathrm{CC}$ in tablets. Subjected to $40^{\circ} \mathrm{C}$ and $75 \% \mathrm{RH}$, the parent drug molecule underwent reactions which resulted in the formation of desethylcandesartan cilexetil and ethylcandesartan cilexetil as main impurities.

Poor solubility and stability of the drug require special conditions when dosage forms are subjected to dissolution tests and dissolution medium should be carefully chosen. From the collected data, a summary of the CC dissolution media recommended in literature was made (Table I). For the purpose of the in vitro release study from CC dosage forms (tablets, nanoemulsions, nanosuspensions, polymeric micelles, self-microemulsifying drug delivery systems (SMEDDS)), dissolution media in the $\mathrm{pH}$ range from 1.0 to 7.2 were selected. Considering the solubility and stability of $\mathrm{CC}$, a dissolution media such as the phosphate buffers pH 7.2, pH 6.8 (with $0.1 \% \mathrm{~T} 20$ ), and $\mathrm{pH} 6.5$ (with $0.02 \% \mathrm{~T} 20$ ) were recommended. Despite the indicated poor solubility [6] and susceptibility to hydrolysis into desethylcandesartan [11] in the acidic medium, dissolution tests were carried out in the acetate buffer $\mathrm{pH} 4.5$, $0.1 \mathrm{~mol} / \mathrm{L} \mathrm{HCl}$ and simulated gastric fluid at $\mathrm{pH} 1.2$.

The aims of the present study were to investigate the solubility of $\mathrm{CC}$ in the selected dissolution media and to indicate the kinetics of CC degradation in the aqueous solution as a function of $\mathrm{pH}$, temperature, surfactant concentration, and buffer type at different pHs (1.2-7.4). The obtained data should be helpful in selecting an appropriate acceptor fluid for dissolution testing.

\section{MATERIALS AND METHODS}

\section{Chemicals}

Candesartan cilexetil (CC) was kindly donated by Polpharma S.A. Pharmaceutical Works (Starogard, Poland). Acetonitrile (Merck, Darmstadt, Germany) and methanol (POCh, Gliwice, Poland) were of HPLC grade. Sodium hydroxide, dipotassium phosphate, and phosphoric acid were purchased from POCh as reagents for preparation of buffered solutions. High-purity water was prepared by use of a Millipore Elix 3 (Millipore, Bedford, MA, USA) water purification system. Phosphate-buffered saline (PBS $0.05 \mathrm{~mol} / \mathrm{L}$ ) $\mathrm{pH} 4.5, \mathrm{pH} 6.5$, and $\mathrm{pH} 7.4$ were prepared by dissolving potassium dihydrogen phosphate in water and adjusting it to a desired $\mathrm{pH}$ with $0.1 \mathrm{~mol} / \mathrm{L}$ of sodium hydroxide. In the same way, PBS pH 6.5 at concentrations of 0.01 and $0.2 \mathrm{~mol} / \mathrm{L}$ was prepared. The $\mathrm{pH}$ was measured at room temperature ( $\mathrm{pH}$-meter (type 350), Orion Research, Boston, USA). Ionic strengths were $0.05,0.079$, and $0.123 \mathrm{~mol} / \mathrm{L}$ for $\mathrm{pH} 4.5$, $\mathrm{pH} 6.5$, and $\mathrm{pH} 7.4$ buffer solutions $(0.05 \mathrm{~mol} / \mathrm{L})$, respectively. Hydrochloric acid ( $\mathrm{HCl}$; POCh, Gliwice, Poland) was used in the concentration of $0.1 \mathrm{~mol} / \mathrm{L}$ (the measured $\mathrm{pH}$ was 1.2 ). Polysorbate 20 (T20, Tween 20) was purchased from Sigma Aldrich (Steinheim, Germany). Solutions containing either $0.35 \%$ or $0.7 \%(\mathrm{w} / \mathrm{w})$ of $\mathrm{T} 20$ were prepared by dissolving the surfactant in $0.1 \mathrm{~mol} / \mathrm{L} \mathrm{HCl}$ or $0.05 \mathrm{~mol} / \mathrm{L} \mathrm{PBS}$ pHs 4.5 and 6.5 .

\section{HPLC Analysis}

Chromatographic separation and quantitative analysis were performed using HPLC apparatus (Merck-Hitachi, Darmstadt, Germany) equipped with C18 column (5 $\mu \mathrm{m}$ LiChrosphere $250 \times$ $4 \mathrm{~mm}$, Merck) and UV-Vis detector at $215 \mathrm{~nm}$. A mixture of $0.05 \mathrm{~mol} / \mathrm{L}$ of phosphate buffer $\mathrm{pH}$ 3.0:acetonitrile:methanol $(30: 50: 20 \mathrm{v} / \mathrm{v})$ was used as a mobile phase. Prior to injection, the samples were diluted with methanol.

\section{HPLC Validation}

The method was validated for the limit of quantification (LOQ) and limit of detection (LOD), linearity, accuracy, and precision. A stock solution of CC $(1 \mathrm{mg} / \mathrm{ml})$ was prepared in methanol, and further dilution was also made in the same solvent.

\section{Linearity}

The linearity of the method was checked by analyzing six solutions of $\mathrm{CC}$ in the concentration range of $0.2-$ $10.0 \mu \mathrm{g} / \mathrm{mL}$ and prepared in triplicate. The least-squares linear regression analysis of the peak area and concentration data was performed. 
Table I. Dissolution Media Used for Biopharmaceutical In Vitro Studies of Candesartan Cilexetil (CC) in Dosage Forms

\begin{tabular}{|c|c|c|c|}
\hline \multirow[b]{2}{*}{ Dosage form of CC } & \multicolumn{2}{|c|}{ Dissolution medium } & \multirow[b]{2}{*}{ References } \\
\hline & Recommended & Other investigated solutions & \\
\hline Tablets & $0.35 / 0.7 \%$ T20 in $0.05 \mathrm{~mol} / \mathrm{L}$ PBS pH 6.5 & - & [14] \\
\hline Tablets & PBS pH 7.2 & $\begin{array}{c}\text { PBS pH } 6.5 \\
\text { Water } \\
0.1 \mathrm{~mol} / \mathrm{L} \mathrm{HCl}\end{array}$ & [19] \\
\hline Tablets & $1 \%$ SLS pH 6.8 & $\begin{array}{l}0.1 \mathrm{~mol} / \mathrm{L} \mathrm{HCl} \\
\mathrm{PBS} \mathrm{pH} 7.0\end{array}$ & [20] \\
\hline Fast-dissolving tablets & Sorenson's buffer $\mathrm{pH} 6.8$ & - & [21] \\
\hline Fast-dissolving tablets & $0.1 \%$ T20 in PBS pH 6.8 & - & [22] \\
\hline Nanosuspension/tablets & PBS pH 6.8 & $\begin{array}{c}0.1 \mathrm{~mol} / \mathrm{L} \mathrm{HCl} \\
\text { Acetate buffer pH } 4.5 \\
\text { Water }\end{array}$ & [10] \\
\hline Nanosuspension & $0.7 \%$ T 20 in $0.05 \mathrm{~mol} / \mathrm{L}$ PBS pH 6.5 & - & [9] \\
\hline Nanoemulsion & $\begin{array}{l}0.1 \mathrm{~mol} / \mathrm{L} \mathrm{HCl} \\
\mathrm{PBS} \mathrm{pH} 6.8 \\
\text { Artificial intestine juice (AIJ) } \mathrm{pH} 6.8\end{array}$ & - & [23] \\
\hline Microspheres & PBS pH 6.8 & - & [24] \\
\hline Polymeric micelles & $\begin{array}{l}\text { Simulated gastric fluid (SGF) pH 1.2, } \\
\text { after } 2 \mathrm{~h} \mathrm{pH} 7.2\end{array}$ & - & [7] \\
\hline Solid lipid nanoparticles & $\begin{array}{l}0.1 \mathrm{~mol} / \mathrm{L} \mathrm{HCl} \\
\mathrm{PBS} \mathrm{pH} 6.8\end{array}$ & - & [25] \\
\hline SMEDDS & $0.02 \% \mathrm{~T} 20$ in $0.05 \mathrm{~mol} / \mathrm{L}$ PBS pH 6.5 & - & {$[8,26]$} \\
\hline
\end{tabular}

$C C$ candesartan cilexetil, $S L S$ sodium lauryl sulfate, $P B S$ phosphate buffer solution, $T 20$ polysorbate 20, SMEDDS self-microemulsifying drug delivery system, $H C L$ hydrochloric acid

\section{Limits of detection (LOD) and quantification ( $L O Q)$}

The LOQ and LOD of the method were determined, based on signal-to-noise ratios. LOD was determined as the lowest CC concentration which can be detected by the HPLC system producing a signal-to-noise ratio of about 3. LOQ was the concentration producing a signal-to-noise ratio of 10 .

\section{Accuracy and precision}

The intra-day and inter-day accuracy and precision were established using samples at the concentrations of 10.0, 5.0, and $1.0 \mu \mathrm{g} / \mathrm{mL}$ in triplicate. The accuracy was defined as the recovery percentage, and precision was expressed as the percent relative standard deviation (RSD).

\section{Solubility Determination}

$\mathrm{CC}$ was added, in excess, into pure solvents (water, $0.1 \mathrm{~mol} / \mathrm{L} \mathrm{HCl}$, PBS $4.5, \mathrm{PBS} 6.5$ ) or to the solvents with addition of $0.35 \%$ or $0.7 \%(\mathrm{w} / \mathrm{w})$ of $\mathrm{T} 20$ and the resulting suspensions were shaken for $24 \mathrm{~h}$ under thermostated circumstances $\left(310 \mathrm{~K}\right.$, i.e., $\left.37^{\circ} \mathrm{C}\right)$ to obtain the solubility

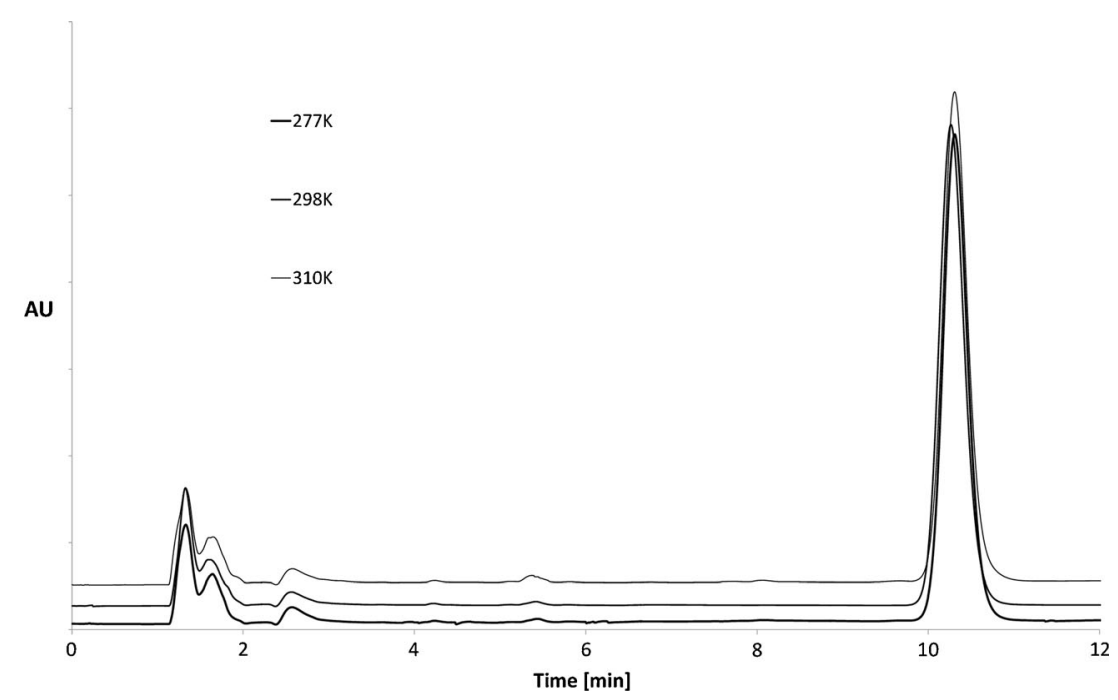

Fig. 2. The HPLC chromatograms of candesartan cilexetyl methanolic solutions after 14 days storage at temperature 277,298 , and $310 \mathrm{~K}$ 
Table II. The Effect of Polysorbate 20 (T20) on Solubility of Candesartan Cilexetil $(\mathrm{Mg} / \mathrm{ml})$ in Dissolution Media at Temperature $310 \mathrm{~K}(n=3$; mean $\pm \mathrm{RSD})$

\begin{tabular}{|c|c|c|c|c|}
\hline \multirow[b]{2}{*}{ Solvent } & \multirow{2}{*}{$\begin{array}{c}\mathrm{pH} \\
\text { value }\end{array}$} & \multicolumn{3}{|c|}{$\mathrm{T} 20(\% \mathrm{w} / \mathrm{w})$} \\
\hline & & 0 & 0.35 & 0.7 \\
\hline $\begin{array}{l}\mathrm{HCl} \\
0.1 \mathrm{~mol} / \mathrm{L}\end{array}$ & 1.0 & $0.23( \pm 47.8)$ & $6.2( \pm 15.3)^{\mathrm{b}}$ & $11.5( \pm 9.5)^{\mathrm{c}}$ \\
\hline $\begin{array}{l}\text { PBS } 4.5 \\
0.05 \mathrm{~mol} / \mathrm{L}\end{array}$ & 4.5 & $0.51( \pm 37.2)^{\mathrm{a}}$ & $7.8( \pm 12.1)^{\mathrm{b}}$ & $20.1( \pm 8.1)^{\mathrm{c}, \mathrm{d}}$ \\
\hline PBS 6.5 & 6.5 & & & \\
\hline $0.01 \mathrm{~mol} / \mathrm{L}$ & & $<0.05$ & $168.8( \pm 2.3)$ & $313.7( \pm 7.8)^{\mathrm{c}, \mathrm{d}}$ \\
\hline $0.05 \mathrm{~mol} / \mathrm{L}$ & & $0.8( \pm 25.8)^{\mathrm{a}}$ & $192.9( \pm 3.9)^{b}$ & $353.4( \pm 9.4)^{\mathrm{c}, \mathrm{d}}$ \\
\hline $0.2 \mathrm{~mol} / \mathrm{L}$ & & $1.3(32.1)^{\mathrm{a}}$ & $201.5( \pm 5.0)^{\mathrm{b}}$ & $620.3( \pm 6.5)^{\mathrm{d}}$ \\
\hline Water & 6.8 & $1.4( \pm 27.2)^{\mathrm{a}}$ & $7.4( \pm 7.3)^{\mathrm{b}}$ & $10.3( \pm 6.9)^{\mathrm{c}}$ \\
\hline
\end{tabular}

Statistically significant difference $(p<0.05)$

$H C L$ hydrochloric acid, $P B S$ phosphate buffer solution, $T 20$ polysorbate 20

${ }^{a}$ Compared with $\mathrm{HCl}$

${ }^{b}$ Compared with PBS $6.5(0.01 \mathrm{~mol} / \mathrm{L})$

${ }^{c}$ Compared with PBS $6.5(0.2 \mathrm{~mol} / \mathrm{L})$

${ }^{d}$ Compared with $\mathrm{HCl}$

equilibrium (no further increase in dissolved drug concentration was observed after $48 \mathrm{~h}$ ). The amount of T20 was added according to FDA dissolution methods [14]. To demonstrate the effect of PBS concentration with $\mathrm{pH} 6.5$ on $\mathrm{CC}$ solubility, the experiment was performed in $0.01,0.05$, and
$0.2 \mathrm{~mol} / \mathrm{L}$ PBS (with and without T20). The samples of saturated solutions were collected after filtration through a $0.22 \mu \mathrm{m}$ filter (cellulose acetate filter, Sartorius, Goettingen, Germany) and diluted appropriately with methanol to prevent the crystallization of the solute. The concentrations of CC were analyzed by the HPLC method.

\section{Stability Study}

Degradation of $\mathrm{CC}$ was studied in solutions prepared with $0.1 \mathrm{~mol} / \mathrm{L} \mathrm{HCl}(\mathrm{pH} 1.2), 0.05 \mathrm{~mol} / \mathrm{L} \mathrm{PBS}(\mathrm{pHs} 4.5$, 6.5, and 7.4), and in water (W-6.8) ( $\mathrm{pH} 6.8$; measured in $10 \mu \mathrm{g} / \mathrm{ml}$ aqueous solution of CC). Experiments were repeated in solutions containing $0.35 \%$ or $0.7 \%$ of $\mathrm{T} 20$ in $0.1 \mathrm{~mol} / \mathrm{L} \mathrm{HCl}$ and $\mathrm{PBS} \mathrm{pH} 4.5$ or 6.5 . The solutions were prepared at the concentration of $10 \mu \mathrm{g} / \mathrm{mL}$ by diluting a $1 \mathrm{mg} / \mathrm{mL}$ methanolic stock solution; the final concentration of methanol in the solutions was approximately $1 \%$. Solutions of $\mathrm{CC}$ in methanol were also subjected to stability studies.

The investigated solutions were stored for 14 days in temperature-controlled areas at 277,298 , and $310 \mathrm{~K}\left(4^{\circ} \mathrm{C}\right.$, $25^{\circ} \mathrm{C}$, and $\left.37^{\circ} \mathrm{C}\right)$. Aliquots were withdrawn at appropriate time intervals and, after diluting with methanol, were immediately analyzed for the remaining CC. The observed pseudofirst-order degradation rate constants, $k_{\text {obs }}$, were calculated from the slopes of the natural-logarithmic plots of the remaining drug fraction versus time in accordance with a

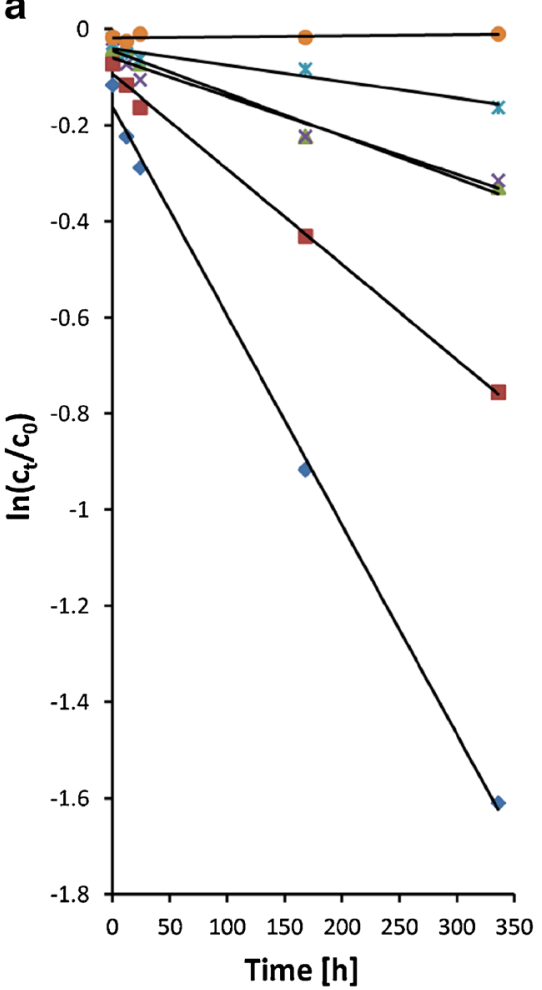

$-\mathrm{HCl}$ b

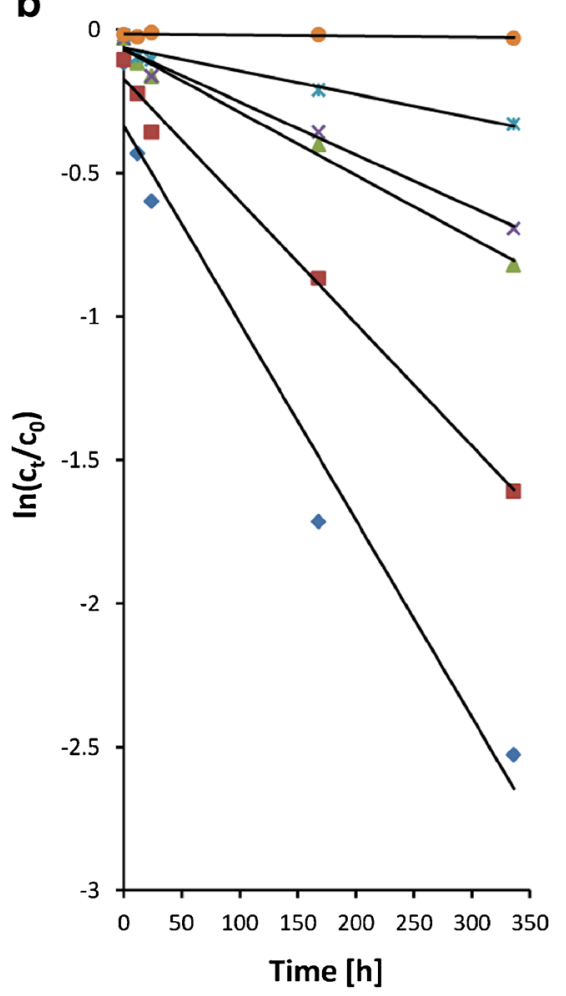

PBS4.5 $\triangle$ PBS6.5
C

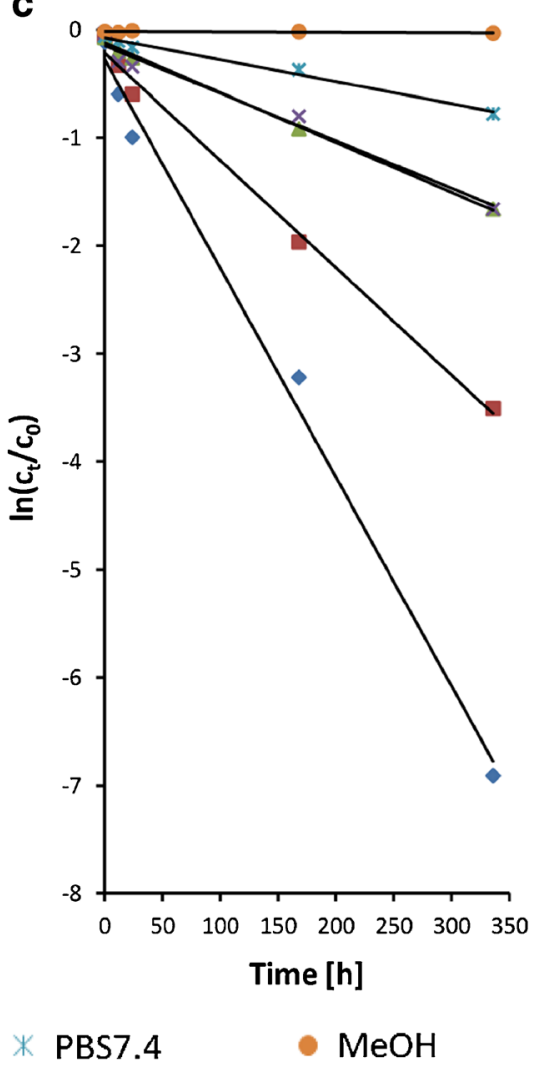

Fig. 3. Pseudo-first-order plots showing the degradation of candesartan cilexetil at temperature: a $277 \mathrm{~K}$, b $298 \mathrm{~K}$, and c $310 \mathrm{~K}$ in aqueous solutions in the $\mathrm{pH}$ range $1.2-7.4$ and in methanolic solution $(\mathrm{MeOH}) ;$ mean values are presented $(n=5 ; \mathrm{RSD}<10 \%)$ 


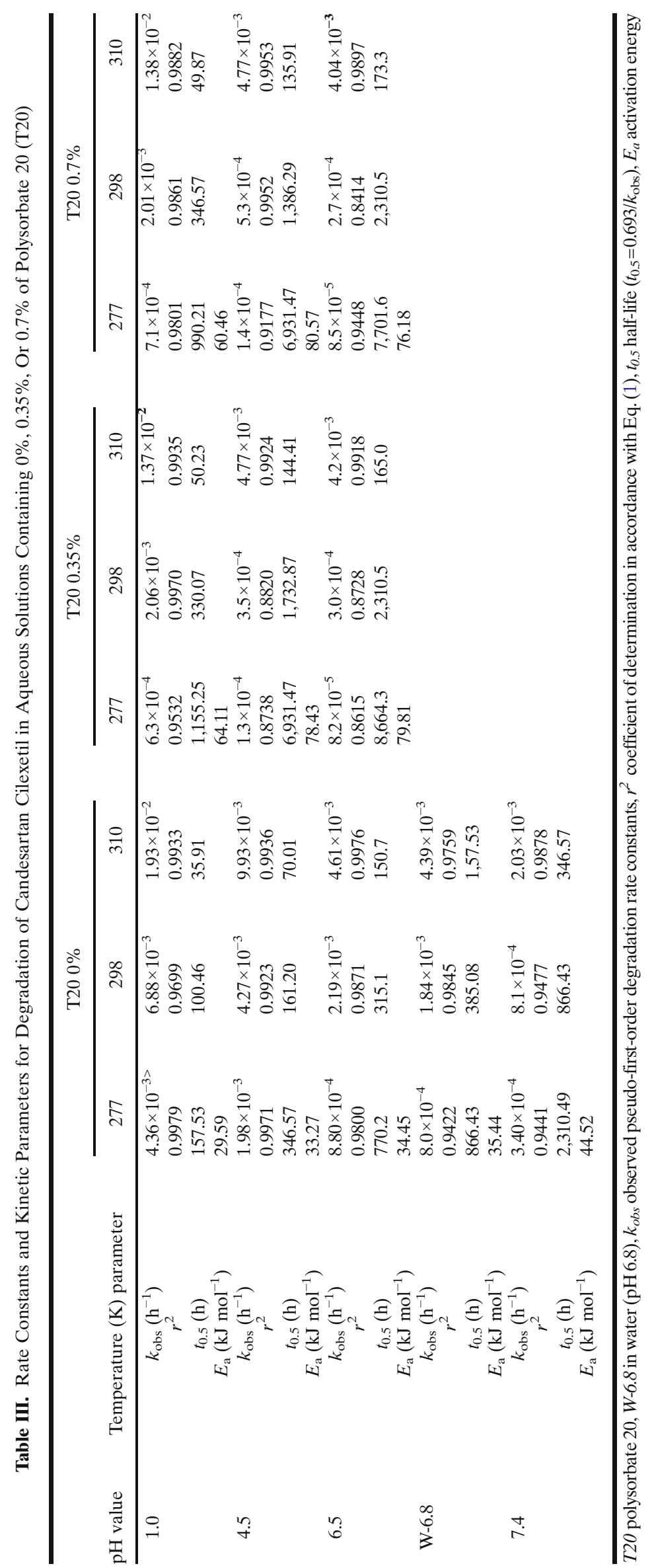


Eq. (1) [15]: where $C_{0}$ is the initial concentration and $C_{t}$ is the concentration of $\mathrm{CC}$ at time $t$ :

$\ln \left(\frac{C_{t}}{C_{o}}\right)=-k_{o b s} t$

Coefficient of determination, $r^{2}$ was used in linear regression analysis to evaluate how the experimental data fit the pseudo-first-order degradation kinetics.

The number of $C_{t}$ measurements taken over the time span from $t_{0} \rightarrow t$ ranged at 5 . The Arrhenius factor $(A)$ and the activation energy $\left(E_{\mathrm{a}}\right)$ for CC degradation were determined from a plot of $\ln \left(k_{\mathrm{obs}}\right)=f(1 / \mathrm{T})$ according to Eq. (2), using the least-squares regression: where $R$ is the universal gas constant and $T$ is the absolute temperature $(\mathrm{K})$.

$\ln k_{\text {obs }}=\ln A-\frac{E_{\mathrm{a}}}{R T}$

\section{RESULTS AND DISCUSSION}

\section{Validation of HPLC}

Concentrations of $\mathrm{CC}$ in solutions were measured using the HPLC method previously described by Lunn [16] and modified for the purpose of this study. An example of the chromatogram is presented in Fig. 2. The least-squares linear regression analysis revealed the linearity in the concentration range of $0.2-10.0 \mu \mathrm{g} / \mathrm{mL}$ : the regression line equation was $y=58.076 x+5.99$ and the coefficient of determination $r^{2}$ was 0.9994 . The LOD was $0.05 \mu \mathrm{g} / \mathrm{mL}$ and the LOQ $0.17 \mu \mathrm{g} / \mathrm{mL}$. The method was characterized by the acceptable precision ( $\leq 6.0 \%$ RSD) and accuracy $(94 \%-104 \%)$.

\section{Solubility}

Solubilities of $\mathrm{CC}$ in the aqueous solvents $(\mathrm{HCl}, \mathrm{PBS}$ 4.5, PBS 6.5, and W-6.8), also with an addition of $0.35 \%$ or $0.7 \%$ of $\mathrm{T} 20$ at temperature $310 \mathrm{~K}$ are shown in Table II (the relative standard deviations (RSD) between the repeated determinations were not larger than $10 \%$ ). According to the pharmacopoeial classification, $\mathrm{CC}$ is practically insoluble in water since its solubility was below $100 \mu \mathrm{g} / \mathrm{ml}$ [4]. The $\mathrm{pH}$-dependent solubility profile of CC compound was observed, however, with only slightly better solubility at higher $\mathrm{pH}(0.23 \mu \mathrm{g} / \mathrm{ml}$ at $\mathrm{pH} 1.2$ and $1.40 \mu \mathrm{g} / \mathrm{ml}$ at $\mathrm{pH} 6.8$ ).

As determined by Satturwar et al. [7], the solubilities of $\mathrm{CC}$ at temperature of $310 \mathrm{~K}$ in a simulated gastric fluid with $\mathrm{pH} 1.2(0.6 \mu \mathrm{g} / \mathrm{ml})$ and in a simulated intestinal fluid with $\mathrm{pH} 7.2(8.6 \mu \mathrm{g} / \mathrm{ml})$, although larger than reported in the present study, are consistent with respect to $\mathrm{pH}$-dependent solubility. This relationship can be supported by an acid-base equilibrium reported by Cagigal et al. [17], who determined $\mathrm{p} K_{a}$ at the value 6.3 for $\mathrm{CC}$ and attributed it to the deprotonation of the tetrazole group classifying $\mathrm{CC}$ as a weak acid. The $\mathrm{pH}$-dependent solubility of CC was studied also by Nekkanti et al. [10], who concluded that the solubility decreases with an increasing $\mathrm{pH}$, however, that was not demonstrated by the experimental results since, for micronized $\mathrm{CC}$, no effect of $\mathrm{pH}$ was observed and, for nonmicronized substance, the solubility at pHs 4.5 and 6.8 was the same.

The solubility enhancement of poorly soluble drugs, required for the dissolution studies from drug formulation, can be achieved by using surfactants. In the present work, the solubility of $\mathrm{CC}$ in water or buffers was enhanced using T20 according to FDA recommendation (Table I). The surfactant was used in concentrations much above the critical micellar concentration (CMC for T20 is, according to different literature sources, $0.001 \%-0.007 \% w / v)$. T20 has significantly increased the solubility of $\mathrm{CC}$ in all solvents, with a larger effect (1.3-2.5 times larger) observed at higher concentration, i.e., $0.7 \%$. Since the drug is solubilized in micelles, the solubility should be considered as an apparent solubility.

At least 2.5 times lower solubility of CC $(125 \pm 6.9 \mu \mathrm{g} /$ $\mathrm{ml}$ ) in PBS $\mathrm{pH} 6.5$ containing $0.7 \%$ of $\mathrm{T} 20$, than in the present study, was reported by Detroja et al. [9], but the experiment was performed at room temperature. Thus, the results obtained in the present study at $310 \mathrm{~K}$ are coherent.

Although solubilities of $\mathrm{CC}$ in PBS at $\mathrm{pH} 4.5$ or 6.5 without a surfactant were comparable, but upon addition of T20, a dramatic increase (200-500-fold) of CC solubility was observed at $\mathrm{pH} 6.5$, while the effect was much smaller at pH 4.5 (15-40-fold). The effect of T20 on CC solubility in water $(\mathrm{pH} 6.8)$ was also not so spectacular. It is interesting to note that another surfactant, namely sodium lauryl sulfate, added to PBS with $\mathrm{pH} 6.8$ in the concentration of $1 \%$ did not exhibit such large solubilization effect [10].

The results suggest that micellar solubilization is more effective in the presence of phosphate ions at higher $\mathrm{pH}$. To elucidate this phenomenon, the relationship between PBS concentration $(0.01-0.2 \mathrm{~mol} / \mathrm{L})$ and solubility of $\mathrm{CC}$ in the presence of T20 was studied. It was observed (Table II) that an increased ionic strength of PBS allows to increase drug solubility, especially at higher concentration of T20. This effect is not so large, however, in $0.35 \%$ of T20 solution and does not

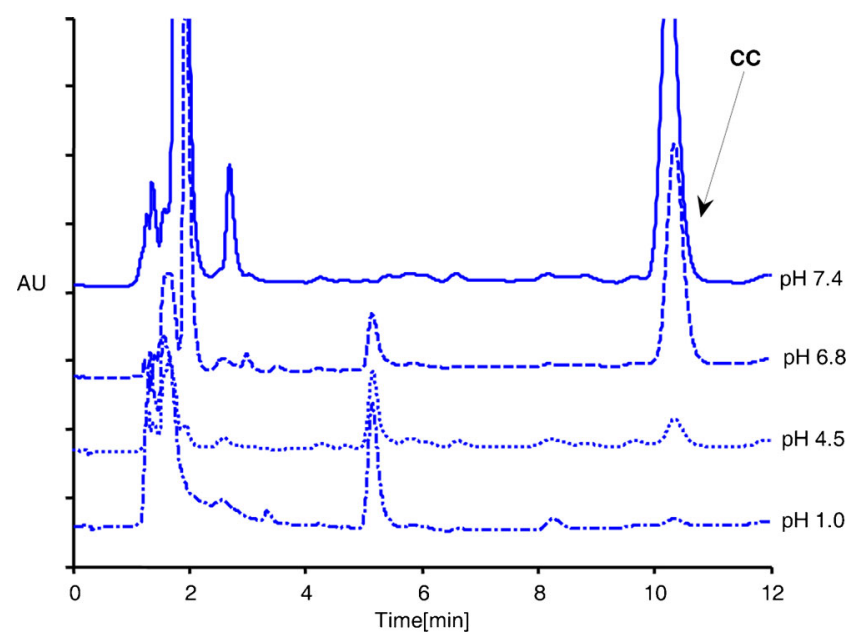

Fig. 4. The HPLC chromatograms of candesartan cilexetil (CC) aqueous solutions $(\mathrm{pH} 1.2-7.4)$ after 14 days storage at $310 \mathrm{~K}$ 
explain a huge difference obtained when T20 is added either to PBS or water. Since T20 is a nonionic surfactant, one cannot explain, without conducting further investigation, the reason for such large solubilization effect only in PBS pH 6.5 but not in water or in PBS pH 4.5.
Results demonstrate that at least 125 and $500 \mathrm{ml}$, respectively, of $0.05 \mathrm{~mol} / \mathrm{L}$ of $\mathrm{PBS}$ at $\mathrm{pH} 6.5$ with $0.35 \%$ of T20 is required for 8 and $32 \mathrm{mg}$ tablets to achieve a minimum "sink" conditions (approximately $30 \%$ of the saturation concentration) in dissolution studies. If T20 is used in concentration a

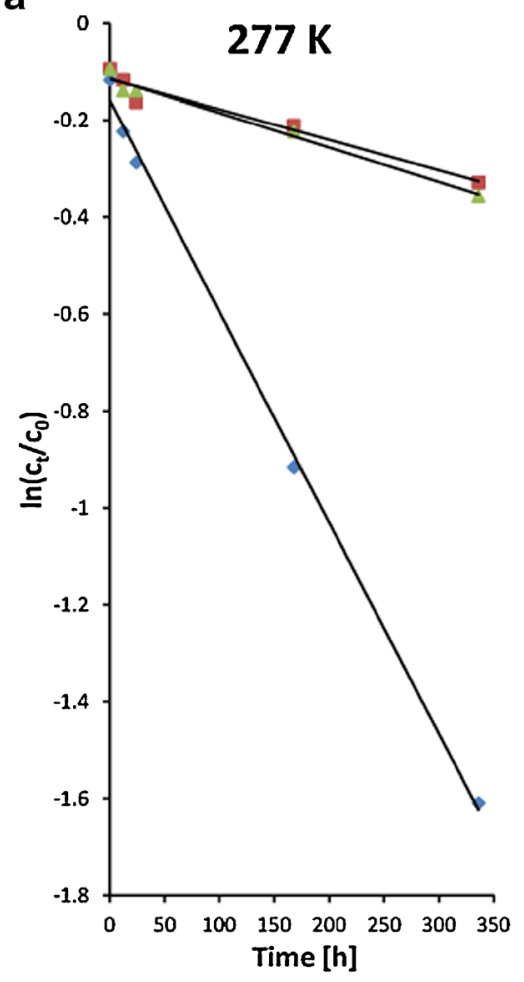

\section{b}

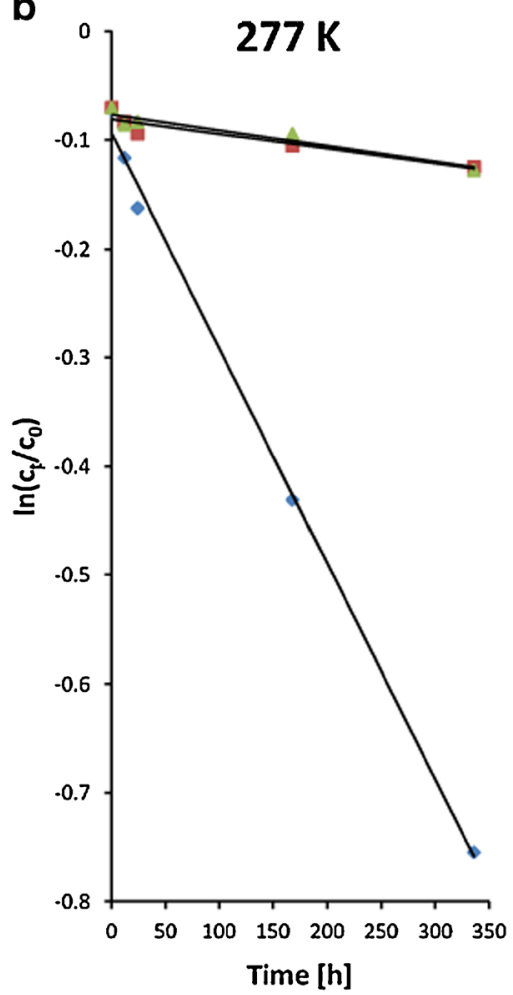

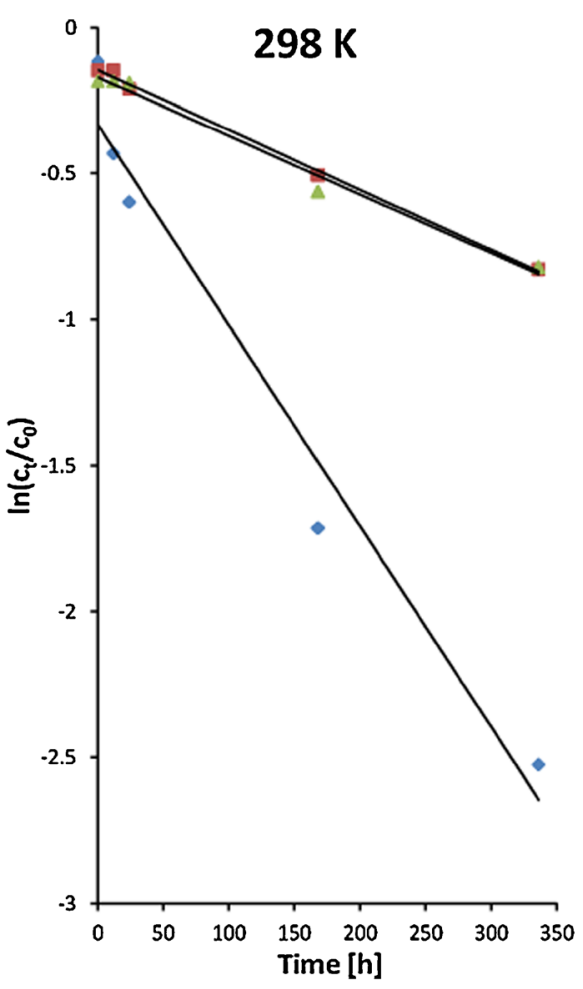
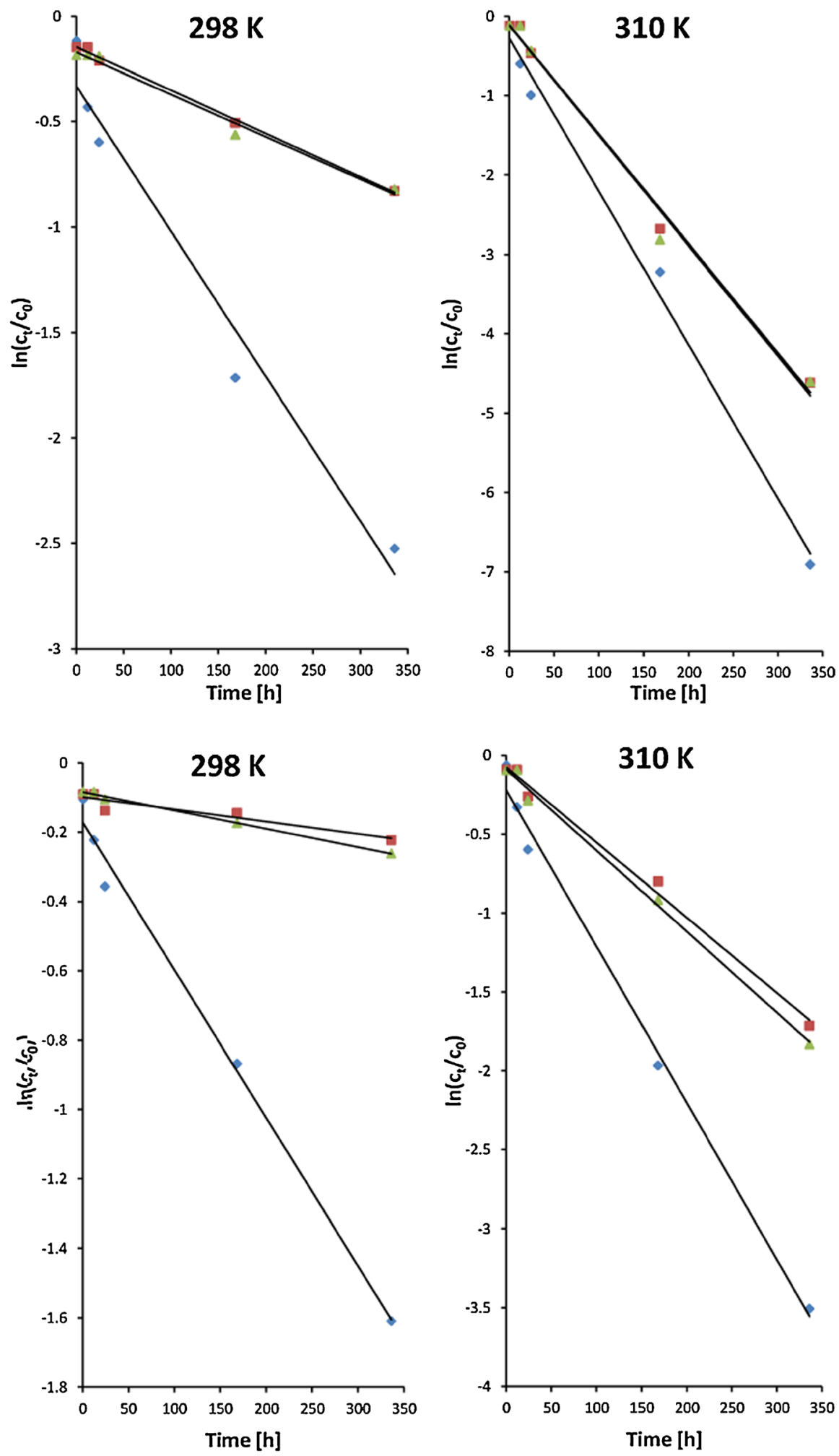

Fig. 5. The effect of polysorbate 20 (T20 0.35 or $0.7 \% \mathrm{w} / \mathrm{w}$ ) on degradation of candesartan cilexetil in $\mathrm{HCl}$ (a) and PBS buffers: pH 4.5 (b) and pH 6.5 (c) at temperature 277, 298, and $310 \mathrm{~K}$; mean values are presented $(n=5 ; \mathrm{RSD}<10 \%)$ 

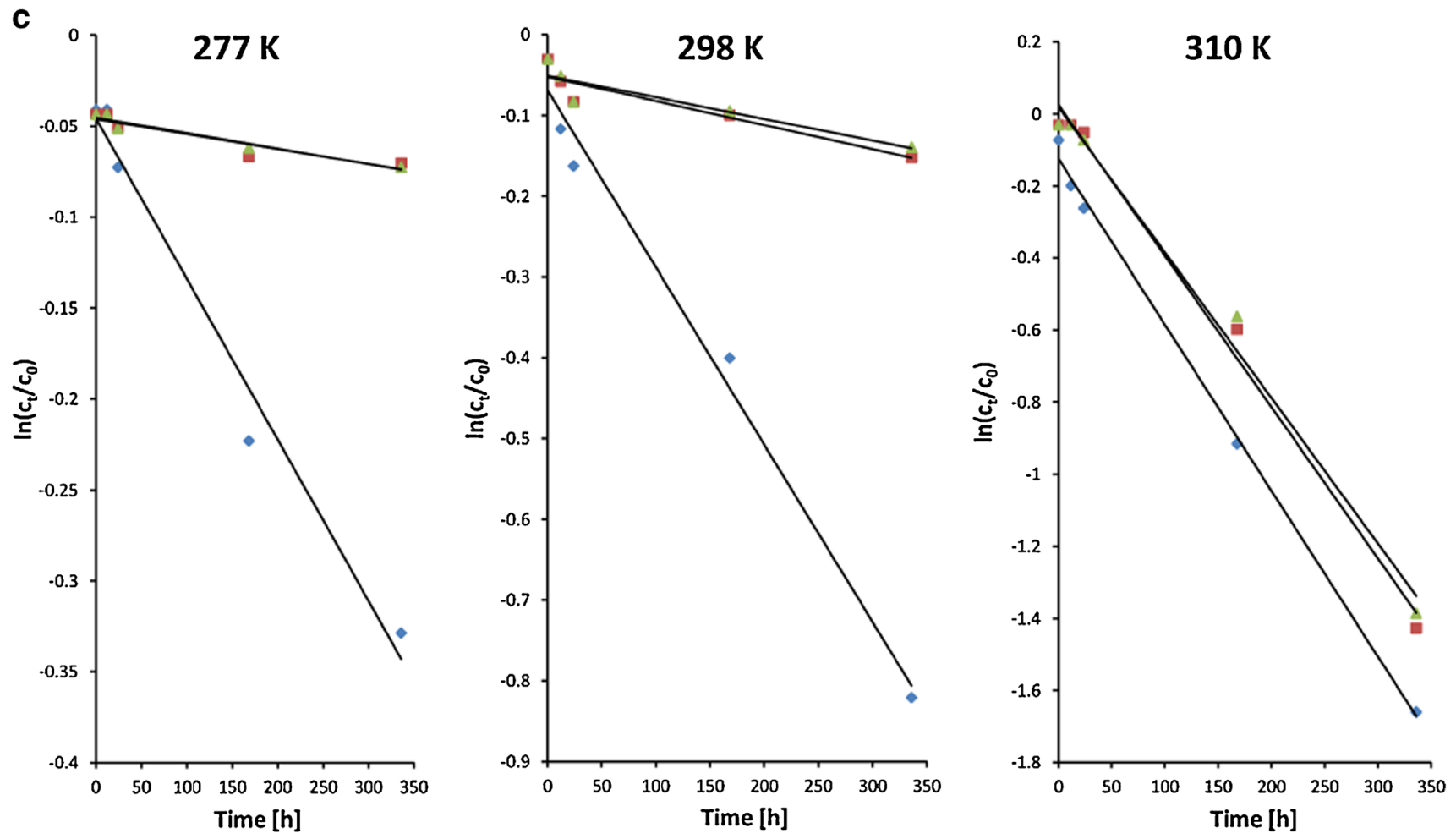

PBS6.5

PBS6.5+0.35T20

$\triangle$ PBS6.5 $+0.7 T 20$

Fig. 5. (continued)

$0.7 \%$, the volumes could be further reduced. On the other hand, the "sink" conditions for $8 \mathrm{mg}$ tablets tested in $\mathrm{HCl}$ or PBS 4.5 would require about $1-2 \mathrm{~L}$ of the medium containing $0.7 \%$ of $\mathrm{T} 20$.

\section{Stability Study}

\section{Methanolic solutions}

$\mathrm{CC}$ in methanolic solution showed good stability with less than $3 \%$ of the total content loss at temperature of $310 \mathrm{~K}$ after 14 days (Fig. 3). In an earlier report, Ferreiros et al. [11] observed that CC degradation occurred in the methanolic solution only upon evaporation. The formation of candesartan and its ester was attributed to the basic hydrolysis of $\mathrm{CC}$ and transesterification reaction of the pro-drug. However, CC derivatives did not appear in our HPLC chromatograms when the methanolic solutions were heated but not evaporated to dryness.

\section{Aqueous solutions - $p H$ and temperature effect}

The most important factors that affect the stability of substances in solutions are $\mathrm{pH}$ and temperature; therefore, the stability of $\mathrm{CC}$ at three different temperatures (277, 298 , and $310 \mathrm{~K}$ ) and at five different $\mathrm{pHs}$ (1.2, 4.5, 6.5, 6.8, and 7.4) was investigated. Figure 3 presents the applicability of the pseudo-first-order model. The selected model showed a linear relationship between the logarithm of concentration $C_{t} / C_{0}$ and the storage time $\left(r^{2}\right.$ in the range of 0.9979 to 0.8414 are presented in Table III).
This indicates that the pseudo-first-order model can be used for predicting the kinetics of the CC degradation in aqueous solutions. The degradation rate profiles show fast decomposition in solution when temperature increases and $\mathrm{pH}$ decreases.

In Table III, the calculated pseudo-first-order rate constants are listed showing the effect the temperature and $\mathrm{pH}$ have on the degradation rates. The $\mathrm{pH}$-rate profiles reveal fast degradation of $\mathrm{CC}$ in acidic conditions. On the basis of the Arrehnius relationship (Eq. (2)), the linear plots of $\ln k_{\text {obs }}$ versus $1 / \mathrm{T}$ were used to calculate the energy of activation. The degradation rate of $\mathrm{CC}$ increases with a decreasing $\mathrm{pH}$ in the following order: PBS7.4<W $(\mathrm{pH} 6.8)<\mathrm{PBS} 6.5<\mathrm{PBS} 4.5<\mathrm{HCl}$. The lowest energy of activation was observed for the acidic solution $(\mathrm{pH} 1.2)$ and it was $29.59 \mathrm{~kJ} / \mathrm{mol}$. The change of $\mathrm{pH}$ from 1.2 to 7.4 results in a 1.5 -fold increase of activation energy and, depending on temperature, 8-14-fold decrease of degradation rate $\left(k_{\mathrm{obs}}\right)$.

Change of temperature from 277 to $310 \mathrm{~K}$ caused 4.4 to 6.6-fold increase in the rate constants, depending on the solvent. After $24 \mathrm{~h}(310 \mathrm{~K})$ in $\mathrm{HCl}(\mathrm{pH} 1.2)$, the $\mathrm{CC}$ content was at $37.0 \%$ of the initial value while in PBS7.4 was at $83.5 \%$. The half-lives of degradation were calculated to be from 1.5 day ( $\mathrm{pH} 1.2,310 \mathrm{~K})$ to 96 days ( $\mathrm{pH} 7.4,277 \mathrm{~K})$.

Accelerated conditions result in hydrolysis and formation of candesartan in an alkaline environment and desethyl CC in acidic and neutral conditions [12, 13, 18]. This is explained by the ionization occurring mainly above $\mathrm{pH} 6.3\left(\mathrm{p} K_{a}\right.$ of $\left.\mathrm{CC}\right)$. The resulting $\mathrm{CC}$, in an ionized form, is highly susceptible to hydrolysis, which leads to the formation of candesartan, while in the nonionized 
form of $\mathrm{CC}$, the ether bond between benzimidazole and ethyl moiety is broken [11, 12, 17].

Figure 4 presents HPLC chromatograms of CC aqueous solutions after 14 days of storage at $310 \mathrm{~K}$. According to literature data $[11,18]$, the peaks at retention times of 1.9 and $5.2 \mathrm{~min}$ were identified as a candesartan and desethyl $\mathrm{CC}$, respectively. In acidic and neutral conditions $(\mathrm{pH} \leq 6.8)$, an identical major degradation product was observed, represented by a peak with the retention time $5.2 \mathrm{~min}$. Degradation of CC in PBS7.4 proceeded with the formation of a major degradation product, with a peak at the retention time of 1.9 min.

\section{The effect of polysorbate 20}

Figure 5 and Table III demonstrate the effect of micellar solubilization of $\mathrm{CC}$ on its stability in an aqueous environment, dependent on $\mathrm{pH}$ and temperature. The protective effect of T20 is clearly visible, similar both in acidic and neutral solvents. The calculated energy of activation was approximately two times higher than for the solutions without T20, but the stability was not further increased with the increasing concentration of T20 from $0.35 \%$ to $0.7 \%$.

The protective effect was decreasing, however, with an increased temperature and was only moderate or small at $310 \mathrm{~K}$ (relevant for a dissolution test). For example, in the presence of T20, in acidic conditions, $k_{\mathrm{obs}}$ decreased only by $28 \%$ and by $13 \%$ in $\mathrm{pH} 6.5$.

Using the calculated $k_{\text {obs }}$ values, one can estimate the degradation level occurring when a typical dissolution test is performed during $1 \mathrm{~h}$ (nonmodified drug release formulations) or during $24 \mathrm{~h}$ (modified dosage forms). If T20 is used $(0.35 \%$ or $0.7 \%)$ in $\mathrm{pH} 6.5$, one can expect the degradation to be at the level of $0.4 \%(1 \mathrm{~h})$ and $9.3 \%$ $(24 \mathrm{~h})$. In acidic $(\mathrm{HCl})$ conditions, these values are $1.4 \%$ and $28.3 \%$, respectively. Thus, the dissolution test at $\mathrm{pHs}$ 1-6.8, required for a bio-waiver, may be performed for conventional tablets or capsules without the danger of degradation, but for longer tests, required for prolonged release formulations, the acceptor fluids at $\mathrm{pH} 6.5$ or higher are suitable under the condition that the degradation is carefully monitored and the flow-through apparatus with a nondelayed analysis is recommended.

\section{CONCLUSIONS}

$\mathrm{CC}$ is practically insoluble in water, and the addition of a surfactant is required to achieve the "sink" conditions during a dissolution test. T20, a surfactant recommended by FDA, dramatically increases the solubility of $\mathrm{CC}$ in a neutral phosphate buffer solution, while its effect at lower $\mathrm{pH}$ or in water is much smaller. The effect was not correlated, however, with the phosphate buffer concentration. The use of T20 $0.35 \%$ solution in PBS at $\mathrm{pH} 6.5$ enables to achieve the sink conditions in the volume of acceptor fluid even as small as $500 \mathrm{ml}$ (for $32 \mathrm{mg} \mathrm{CC}$ doses), and this volume can be further reduced by using $0.7 \%$ of T2 2 solution in PBS. However, if a pH-dependent dissolution profile is necessary, the required volume of the acidic acceptor fluid is too large, since T20 does not increase CC solubility in acidic conditions so dramatically.

The choice of neutral $\mathrm{pH}$ for dissolution studies is also justified by the poor stability of CC in acidic conditions. T20 protects CC from degradation; this effect, however, is temperature-dependent and is practically nonrelevant at $310 \mathrm{~K}$.

Due to a large solubilizing effect of T20 only in PBS solutions, despite of the insignificant effect of this surfactant on $\mathrm{CC}$ stability at $310 \mathrm{~K}$, we were unable to propose a more appropriate acceptor fluid for CC dissolution studies than PBS at $\mathrm{pH} 6.5$ with $\mathrm{T} 20$ at the concentration of up to $0.7 \%$, which FDA recommends.

\section{ACKNOWLEDGMENTS}

This work was supported by the Polish Ministry of Science and Higher Education (grant N N405 624638).

Open Access This article is distributed under the terms of the Creative Commons Attribution License which permits any use, distribution, and reproduction in any medium, provided the original author(s) and the source are credited.

\section{REFERENCES}

1. Pillay V, Fassihi R. Unconventional dissolution methodologies. J Pharm Sci. 1999;88(9):843-51.

2. Brown CK, Chokshi HP, Nickerson B, Reed RA, Rohrs BR, Shah PA. Acceptable analytical practices for dissolution testing of poorly soluble compounds. Pharm Technol. 2004;28(12):56-65.

3. Dressman JB, Krämer J. Pharmaceutical dissolution testing. Boca Raton: Taylor \& Francis; 2005.

4. Abrahamsson B, Ödman J, Pharmaceutical composition comprising candesartan cilexetil 2008. http://patentscope.wipo.int/search/ en/WO2008030161. Accessed 13 Sep 2013.

5. Miyabayashi T, Okuda T, Motohashi M, Izawa K, Yashiki T. Quantitation of a new potent angiotensin II receptor antagonist, TCV-116, and its metabolites in human serum and urine. J Chromatogr B Biomed Sci Appl. 1996;677(1):123-32.

6. Al Omari AA, Al Omari MM, Badwan AA, Al-Sou'od KA. Effect of cyclodextrins on the solubility and stability of candesartan cilexetil in solution and solid state. J Pharm Biomed Anal. 2011;54(3):503-9.

7. Satturwar P, Eddine MN, Ravenelle F, Leroux JC. pH-responsive polymeric micelles of poly(ethylene glycol)-bpoly(alkyl(meth)acrylate-co-methacrylic acid): influence of the copolymer composition on self-assembling properties and release of candesartan cilexetil. Eur J Pharm Biopharm. 2007;65(3):379-87.

8. Nekkanti V, Karatgi P, Prabhu R, Pillai R. Solid selfmicroemulsifying formulation for candesartan cilexetil. AAPS PharmSciTech. 2010;11(1):9-17.

9. Detroja C, Chavhan S, Sawant K. Enhanced antihypertensive activity of candesartan cilexetil nanosuspension: formulation, characterization and pharmacodynamic study. Sci Pharm. 2011;79(3):635-51.

10. Nekkanti V, Pillai R, Venkateshwarlu V, Harisudhan T. Development and characterization of solid oral dosage form incorporating candesartan nanoparticles. Pharm Dev Technol. 2009;14(3):290-8.

11. Ferreirós N, Dresen S, Alonso RM, Weinmann W. Hydrolysis and transesterification reactions of candesartan cilexetil observed during the solid phase extraction procedure. J Chromatogr B Analyt Technol Biomed Life Sci. 2007;855(2):134-8.

12. Rao DVS, Radhakrishnanand P, Suryanarayana MV, Himabindu V. A stability-indicating LC method for candesartan cilexetil. Chromatographia. 2007;66(7-8):499-507. 
13. Mohan A, Shanmugavel S, Goyal A, Venkataraman BR, Saravanan D. Identification, isolation, and characterization of five potential degradation impurities in candesartan cilexetil tablets. Chromatographia. 2009;69(11-12):1211-20.

14. FDA. Dissolution Methods 2013. Available from: http:// www.accessdata.fda.gov/scripts/cder/dissolution/dsp_searchresults_ dissolutions.cfm?printall $=1$.

15. O'Byrne PM, Williams R, Walsh JJ, Gilmer JF. The aqueous stability of bupropion. J Pharm Biomed Anal. 2010;53(3):376-81.

16. Lunn G. HPLC methods for recently approved pharmaceuticals. New Jersey: Wiley; 2005.

17. Cagigal E, González L, Alonso RM, Jiménez RM. pKa determination of angiotensin II receptor antagonists (ARA II) by spectrofluorimetry. J Pharm Biomed Anal. 2001;26(3):477-86.

18. Mehta S, Shah RP, Priyadarshi R, Singh S. LC and LC-MS/TOF studies on stress degradation behaviour of candesartan cilexetil. J Pharm Biomed Anal. 2010;52(3):345-54.

19. Kamalakkannan V, Puratchikody A, Ramanathan L, Jayapraba $\mathrm{S}$. Development and validation of a dissolution test with reversedphase high performance liquid chromatographic analysis for candesartan cilexetil in tablet dosage forms. Arab J Chem. 2011. doi:10.1016/j.arabjc.2011.09.011.

20. Revathi R, Ethiraj T, Marreddy JL, Ganeshan V. Development and validation of a dissolution test for candesartan cilexetil in tablet forms using reverse phase- -high performance liquid chromatography. J Pharm Educ Res. 2011;2(2):71-7.

21. Gurunath S, Shailesh S, Patil P, Nanjwade BK. Formulation and evaluation of fast dissolving tablets of candesartan cilexetil by vacuum drying technique. J Pharm Res. 2011;4(11):4195-8.

22. Patil B, Rao N. Formulation and evaluation of fast dissolving tablets of candesartan cilexetil using natural and synthetic superdisintegrants. J Appl Pharm. 2011;3(3):250-61.

23. Gao F, Zhang Z, Bu H, Huang Y, Gao Z, Shen J, et al. Nanoemulsion improves the oral absorption of candesartan cilexetil in rats: performance and mechanism. J Control Release. 2011;149(2):168-74.

24. Mishra V. Formulation and evaluation of matrix microspheres for simultaneous delivery of candesartan cilexetil and captopril for treatment of nephritic syndrome. Int J Pharm Sci Res. 2011;2(11).

25. Zhang Z, Gao F, Bu H, Xiao J, Li Y. Solid lipid nanoparticles loading candesartan cilexetil enhance oral bioavailability: in vitro characteristics and absorption mechanism in rats. Nanomedicine: NBM. 2012;8(5):740-7.

26. Shukla JB, Patel SJ. Formulation and evaluation of self micro emulsifying system of candesartan cilexetil. Int J Pharm Sci. 2010;2(4):143-6. 